\begin{tabular}{c} 
Volume and Issues Obtainable at Center for Sustainability Research and Consultancy \\
Review of Politics and Public Policy in Emerging Economies \\
ISSN: $2708-3829$ \& (E): 2708-356X \\
Volume 3: No. 1, June 2021 \\
CSRC \\
Journal homepage: $\underline{\text { www.publishing.globalcsrc.org/rope }}$ \\
\hline
\end{tabular}

\title{
Single Story Sellers Everywhere: Deconstructing Media Reportage on Banditry in Nigeria
}

*Alfa Patrick Innocent, Department of Social Science and Humanities, The Federal Polytechnic, Idah, Kogi State, Nigeria

Isah Ibn-Mohammed, Department of Social Science and Humanities, The Federal Polytechnic, Idah, Kogi State, Nigeria

Otaida Eikojonwa, Department of Political Science, Federal University Dutsin Ma, Katsina State, Nigeria

*Corresponding author's email: alfaintellectual@gmail.com

\begin{tabular}{l}
\hline ARTICLE DETAILS \\
History \\
Revised format: May 2021 \\
Available Online: Jun 2021 \\
\hline Keywords \\
Media Reportage, Banditry, \\
Militia, Advertisement, \\
Terrorism.
\end{tabular}

JEL Classification $M 0, M 1$

\begin{abstract}
Purpose: The media has been described as the fourth estate of the realm because of the huge role it plays in information dissemination and education. However, when the media peddles narratives to make and or mar one group, the media losses its role ethos and principle of balance and neutrality. Therefore, this work attempts to interrogate imbalance media reportage on the issue of north/south divide on banditry.

Method: The work is qualitative and employs extant literature as its main source.

Findings: The work found out that the media reports the same incidences in different parts of Nigeria in different tones, when violent crimes occur in the north it is simply referred to as banditry but whilst it happens elsewhere, it is called other less derogatory names that do not qualify the extent of the crimes committed.

Implications/Originality/Value: The work recommended among other things that the media must uphold its principles of balanced journalism and help peddle narratives that bind rather than divide.
\end{abstract}

(C) 2021 The authors, under a Creative Commons

Attribution-NonCommercial 4.0

Recommended citation: Innocent, A. P., Mohammed, I. I. and Eikojonwa, O. (2021). Single Story Sellers Everywhere: Deconstructing Media Reportage on Banditry in Nigeria. Review of Politics and Public Policy in Emerging Economies, 3 (1), 27-39.

\section{Introduction}

It is been said that before truth puts its pants on, a lie would have already made it way around the world (Sharyl 2017). The media has been described as the fourth estate of the realm because of 
the important role it plays in todays' world. Indeed, the world is dominated by both print and electronic media, and our perception of reality is increasingly moulded by media-driven narratives. Documentaries and feature films teach us tales about ourselves and the society we live in. In the guise of hyperbole and satire, television responds to us and delivers us "reality." Daily existence is transformed into a story via print journalism. Advertisements tell stories about our desires and fantasies (Helen, 2005).

Although, we live in a world of cultural, socio-economic and political polarization, the $21 \mathrm{st}$ century has been described as a period of accelerated digital and technological revolution where the mass media is primarily saddled with the ethical responsibility of informing the public through balanced reportage that will help citizens make informed decisions about the goings-on in their societies. The media is also responsible for the revival of critical conversations that promote and enhance a healthy democracy and good governance.

Helen opined that the media now controls the production and consumption of narratives across the globe. She argues that the stories that seem most natural are the ones that we've become familiar to from the media and that individual preference of what to watch and listen to is hugely limited by what is available and the content media houses make available out there. (Helen, 2005) As our choices are limited to only what is whispered into our ears thereby allowing us to act upon what is been said to us most times without recourse to the other side of the narrative.

With the debate of balanced reportage on the rise, it is pertinent in the paper to state unequivocally that there is no media outfit that is not "Pro or Anti" something. With a single click of the mouse, information can easily travel across the globe with an incredible speed of light, creating in its wake a huge pool of armchair analyst, vested interest and sophisticated story tellers who would go the extra mile to sell and spread any kind of news be it true of false. Therefore, media bias has become an integral, as media outlets present news reportage, political programmes and talk shows that only serves the interest of their pay master's or those who have the money to spread their own side of the story. Buttressing this, Sharyl strongly argues that politicians, corporations, and other special interests have enlisted the help of media professionals. We give them free reign on the current story. We allow them have a monopoly on the opinions we seek out and quote. Political commentators are plastered all over the press, not presenting independent viewpoints but rather serving their masters. We've hired political operatives as consultants and pundits, and we've even hired them as reporters, anchors, and editors in our newsrooms. We've turned into an eager recipient and disseminator of daily political propaganda. We call it fair because we invite both sides to feed us. In many ways, several media organisations have devolved into more than just thinly veiled propagandists (Sharyl, 2017).

Helen brilliantly corroborated the Sharyl's position when she argued the economics of the media. She opined that the economic function of the media to maximize profit like other businesses, undermines the essence and idea that media narratives have some kind of innate or universal structure common to all humanity. To her, media narratives become simply a way of selling something and the economics of the media industry determines its output generally (Helen, 2005). The media industry in Nigeria is not farfetched from its counterparts across the globe, in that, like most media outfits, they stand for or against something.

To the authors of this paper, the Nigerian mass media has an exceptional reputation for being embarrassingly bias. To subject this to intellectual interrogation for those who might seek to counter this papers standpoint, the authors have chronicled media reportage on the Fulani and or people of northern extraction while juxtaposing incidences across the Niger and the sensationality 
and approach of the media. Indeed, the media in the country with the exception of the few who aspire to balance their reportage has to a great extent succeeded on the one hand in shredding the image of a particular group (Fulani) and have profile them as those with the exclusive prerogative to violence, banditry and terrorism, the media has brilliantly pitched the Nigerian public against them, because of the many gory things said about the Fulani, the average Nigerians now see anything Fulani as synonymous violence.

On the other hand, when similar criminal atrocities are carried out in other parts of the country, they are almost always tagged with a different nomenclature, depending on what media outfit is writing or reporting the crime, they find other adjectives to use such as hoodlums, thugs and unknown gunmen. The argument of this paper is that a crime is a crime and the nomenclature of such crimes should not be determined by place or the people, ethnicity or the religion of those committing such crime. There should be no room for disguising crime in any form. Criminals should be given the same tag irrespective of their political, region, religion or ethnic affiliations.

It is unfortunate that the concept of African authenticity has been enveloped by the imperialist tendencies. As even telling stories today has not escaped our copy and paste syndrome. The western media for example, never refer to white terrorist groups in America and or Europe as terrorists, they are either referred to as militias or white supremist groups.

Ghida (2021) for instance posited that between the periods of 2014 to 2020, there has been two thousand eight hundred and five (2805) mass gun shootings across the United States. In 2020 alone, more than twenty thousand $(20,000)$ Americans lost their lives to mass shooting. This groups have recked monumental havoc and continue to do so (Ghida, 2021). The question that comes to the mind is; what differentiates these seemingly armed violent groups from the violent attacks carried out by bandits or terrorist groups? Their modus operandi may differ but they all have the same objective and a common goal which is to kill, maim, instill fear on innocent and unarmed citizens or to destabilize democratic governments.

Suffice to say, media reportage of violence in Nigeria has clearly shown that most media outlets in Nigeria are not driven by a mission to genuinely inform the public, stimulate a critical, healthy and balanced conversation. The Nigerian media is deeply driven by a pre-determine outcome. One begins to wonder, is our accessibility to news media really helping societies become better informed or do the content of the media serve as stimuli to violence, heighten suspicions and further balkanized Nigerians along ethnic and religious line? This paper intends to interrogate this question and make suggestions for that would benefit the Nigerian media community.

\section{Conceptualization of Some Key Terms \\ Banditry}

The term "banditry" refers to the presence or prominence of armed robbery or other forms of violent crime. It entails the use of force, or the threat of force, to intimidate someone with the intention of robbing, raping, or killing them. Banditry is a crime committed against people. It has long been a popular kind of criminality, as well as a source of violence in modern countries (NigeriaWatch cited in Ahmed, n.d). Banditry is a concept in which one person's terrorist is another person's freedom warrior.

\section{Terrorism}

The United States Department of State's definition of terrorism, published in 1983, is still one of the most extensively used definitions today. It reads: "terrorism is premeditated, politically motivated violence perpetrated against non-combatant targets by sub-national groups or 
clandestine agents, usually intended to influence an audience" (Sinai, 2008:9). Similarly, the United States' Federal Bureau of Investigation (FBI) defines terrorism as "the unlawful use of force or violence against persons or property to intimidate or coerce a government, the civilian population or any segment thereof, in furtherance of political or social objectives" (Shanahan cited in Ziyanda 2018).

\section{Militias}

Within a state, a militia is an equipped sub-state force that conducts security and governance tasks (Stathis, 2006). A militia's main purpose is population control, particularly the formation of local rule in a given area (Adrian 1966). States and insurgent organizations can build or co-opt it, or it can emerge as a competitor to both.

There's no guarantee that militias, especially those recruited from ex-insurgents, won't start fighting the government again in the future. As John Mueller points out, militia "may be troublemakers: rowdy, disobedient, and rebellious, sometimes committing illegal acts while being on (or off) duty that can be damaging or even detrimental to the military organization." Most crucially, militia members may be hesitant to stand and fight when their lives are in peril, and militia members may desert when self-preservation and opportunity meet, according to Mueller (citing Seth 2012).

\section{Media Bias}

Ideology and spin are two high-level types of media bias that Mullainathan and Shleifer define as news outlets' intentions while creating articles. If an outlet biases stories to support a particular point of view on a topic, it is said to have ideological bias. If the media is attempting to generate a memorable tale, there is likely to be spin bias. A generally accepted second definition of media bias separates three types: coverage, gatekeeping, and statement. The visibility of issues or entities, such as a person or a country, in media coverage is referred to as coverage bias. Gatekeeping prejudice, also known as selection bias or agenda bias, refers to how media outlets choose which news to report on and which to ignore. Statement bias, sometimes known as presentation bias, refers to how articles report on ideas. For example, editorial slant impacts the quantity and tone of a newspaper's coverage of a presidential candidate, resulting in a wellobserved prejudice in the US elections. (Mullainathan and Shleifer, as quoted by Felix, Karsten, and Bela in 2018).

\section{Media Literacy}

The ability to think critically about media content is referred to as media literacy. The idea of media literacy can be traced back to the period of yellow journalism where newspaper organizations were just scrambling for readers without recourse to facts. Media literacy, as defined by the National Association for Media Education, is the capacity to use all types of media to access, assess, analyze, act, communicate, and create. 2020 (CMAC).

\section{What, exactly, is a smear?}

Depending on whom you ask. One person's smear is another person's truth. In simple terms, it's an attempt to sway public opinion by spreading an exaggerated, sensational, and destructive story. Often, the purpose is to kill ideas by destroying the people who are best at articulating them. What you may not know is that a lot of this manipulation is done through methods that are utterly invisible to the average consumer. Sponsored forces create ingenious, covert methods to change the whole information landscape in unexpected ways. Their intention is to deceive you. To appear random, public thoughts are methodically planned (Sharyl, 2017). 


\section{Historical Background of Banditry}

In order to understand the media reportage of banditry, it is imperative to take an historical path to understanding the bandit media relation. Banditry has a rich and lucrative history throughout south Asia and despite continued anti banditry efforts, the problem of banditry persists in India presently (Dmella cited in Suleiman and Balkisu, 2020).

Banditry has become a security challenge in Africa where bandits have continued to ravage the horn of Africa, east and central Africa and the trans-Saharan trade routes from Niger Republic all the way to Libya (Aregbesola cited in Suleiman and Balkisu, 2020). Banditry has prevailed in sections of Chad and surrounding Lake Chad, and it is also prevalent in portions of Southern Africa (Aregbesola). The prevalence and severity of banditry in West Africa has contributed to a rise in regional instability, posing a threat towards the subregion's regional integration (Abdullahi, cited in Suleiman and Balkisu, 2020).

Banditry in Africa is characterized by the maiming, murdering, and indiscriminate damage of property, and hence has a clear link to cattle rustling (Rufa'i, 2017:8). Because most herders will do anything to prevent their herds from being rustled, the bandits use force and Small Arms and Light Weapons (SALWs) to ensure that cattle is stolen effectively (Addo, 2006:7) As a result, the use of force during livestock theft is classified as banditry and a dynamic working pattern of crime.

Banditry, according to Anka (2017), may be traced back to over four decades of conflicts involving established farmers and nomads herding groups who roam the high plains of northern Nigeria, primarily in the North West geopolitical zone in states like Zamfara. Banditry in Zamfara State began in 2009 and became more prevalent in 2011, particularly after the general elections. Banditry has disproportionately afflicted people in Nigeria's northwest states of Zamfara, Kaduna, Niger, Sokoto, Kebbi, and Katsina. Approximately 21 million individuals in these states have been exposed to insecurity as a result of banditry (Ahmed n.d).

Since 1999, the scale and severity of violent crime against people, such as murder, rape, and robbery, has increased across Nigeria's six geopolitical zones. The ubiquitous tendency of armed robbery in the country, which in effect parallels the African experience, demonstrates this. The salient lesson therefore, is that banditry is not a new phenomenon as treated in the Nigerian media as a recent occurrence. Criminality and violence is not alien to any part of the country and should be addressed as such. Banditry has historical context within most societies in the African sub region.

\section{Deconstructing Media Reportage}

Media stories do not exist solely to entertain us, as customer, by telling us stories to amuse us or by providing us with services and a variety of options from which to choose. They are built to support the vast economic empires that control the majority of media channels, with the goal of profiting from the commodification of media products and the tales they can convey (Helen, 2005). It is important to note here that, there is no media outfit that is pro-nothing, every media outlet is pro-something.

Every news media by its very nature and establishment has supreme expertise in the act of propaganda and brainwashing of the public, since the public want to hear or read more of scandal, the Nigeria media have excelled in this regard. On daily basis we hear on radio, read 
articles on newspaper or watch news and tv programmes that constantly fuel our curiosity and feeds us with half-truth just to keep us perpetually glue to such media channels and desire for more and more. Sometimes, the intention of media content producer is to create mass hysteria to further strengthen political polarization, ethnic and religious bigotry just to satisfy their audience and the pay masters. Sharyl brilliantly argued that the ability to execute a character assassination becomes more pivotal than any other singular campaign strategy. Operatives spring into action, exploiting the latest technology and tactics. Smears now figure prominently in almost every mainstream news publication. Reporters pursue sordid narratives with the fervor. Smears become embedded in the fabric of our everyday existence. So common, we barely flinch at the most audacious claims. With public skepticism of the news media at an all-time high, a cynical public turns to other sources of information, making it simpler to dupe. Smears and fake news thrive in this environment, which is bereft of morals. It's no longer a stretch for news consumers to believe that the press is covering up important stories or is in the tank for corporate and political interests (Sharyl, 2017).

\section{Media Bias on Violence Reportage in Nigeria: A Chronicle of Newspaper Coverage of Banditry and Related Crimes: Below is a chronicle of the pattern of media reportage on incidences of violent attacks and Media Description of the Acts}

\begin{tabular}{|c|c|c|}
\hline Source & Headline & Perpetrator \\
\hline Dailytrust.com Jan 16/2021 & $\begin{array}{l}\text { How Katsina became hotbed of } \\
\text { banditry: Dailytrust }\end{array}$ & Bandits \\
\hline Dailytrust: Tue Feb 092021 & $\begin{array}{l}\text { At least bandits killed } 21 \text { kidnapped } \\
40 \text { others }\end{array}$ & Bandits \\
\hline Dailytrust.com 3 may 2021 & $\begin{array}{l}\text { We killed students of Kaduna } \\
\text { private varsity to show govt has } \\
\text { failed }\end{array}$ & Bandits \\
\hline $\begin{array}{l}\text { Dailytrust.com. Monday May } 24 \\
2021\end{array}$ & $\begin{array}{l}\text { 'Dining with the devil': How } \\
\text { villagers' co-habit with bandits }\end{array}$ & Bandits \\
\hline Leadership newspaper Jan 252021 & $\begin{array}{l}6 \text { Killed, } 5 \text { Abducted as } \text { Bandits } \\
\text { Displace } 3000 \text { In } \\
\text { Communities }\end{array}$ & Bandits \\
\hline Leadership newspaper Jan 82021 & $\begin{array}{l}2 \mathrm{~m} \quad \text { Nigerians Displaced by } \\
\text { Insurgency, Banditry- FG }\end{array}$ & Bandits \\
\hline Leadership newspaper April 72021 & $\begin{array}{l}\text { Bandits Kill 8, Abduct } 19 \text { Female } \\
\text { Anglican Church Members, } 6 \text { Others } \\
\text { in Kaduna }\end{array}$ & Bandits \\
\hline Leadership newspaper 6 May 2021 & $\begin{array}{l}\text { EXCLUSIVE: Abuja Schools Shut } \\
\text { Down as Truckload of Bandits } \\
\text { Arrives in Border Town }\end{array}$ & Bandits \\
\hline $\begin{array}{l}\text { Sahara Reporters, New York May } \\
19,202\end{array}$ & $\begin{array}{l}\text { BREAKING: Bandits Burn Kaduna } \\
\text { Church, Kill Eight }\end{array}$ & Bandits \\
\hline
\end{tabular}




\begin{tabular}{|c|c|c|}
\hline saharareporters.com > 2021/02/18 & $\begin{array}{l}\text { Getting A Gun Is Like Buying } \\
\text { Bread, Says 'Repentant' Bandits' } \\
\text { Leader Behind Kankara Schoolboys } \\
\text { Abduction, Daudawa }\end{array}$ & Bandits \\
\hline $\begin{array}{l}\text { Www.premiumtimesng.com } 26 \text { Feb } \\
2021\end{array}$ & $\begin{array}{l}\text { SPECIAL REPORT: How bandits } \\
\text { terrorized Kagara for years before } \\
\text { student's abduction }\end{array}$ & Bandits \\
\hline $\begin{array}{l}\text { www.premiumtimesng.com > news } \\
30 \text { April } 2021\end{array}$ & $\begin{array}{l}323 \text { killed, } 949 \text { kidnapped in } \\
\text { Kaduna in three months - Report - } \\
\text { Premium Times Nigeria }\end{array}$ & Bandits \\
\hline $\begin{array}{l}\text { www.premiumtimesng.com } \\
\text { March } 2021\end{array}$ & $\begin{array}{l}\text { Next Post Bandits, Violence and the } \\
\text { Numbers Game, By Jibrin Ibrahim }\end{array}$ & Bandits \\
\hline Punch Newspapers 21 July 2019 & $\begin{array}{l}\text { Bandits getting more intelligence } \\
\text { reports than military' - }\end{array}$ & Bandits \\
\hline Punchng.com 1 May 2021 & $\begin{array}{l}\text { Police continue VIP duties as } \\
\text { bandits, terrorists kill over } 269 \text { in } \\
\text { April }\end{array}$ & Bandits \\
\hline Punch Newspapers 19 May 2021 & $\begin{array}{l}\text { Bandits kill eight, raze houses, } \\
\text { church in Kaduna }\end{array}$ & Bandits \\
\hline Punch Newspapers 24 April 2021 & $\begin{array}{l}\text { Kaduna abductions: Banditry now } \\
\text { war situation, govt should cooperate } \\
\text {-Gumi }\end{array}$ & Bandits \\
\hline $\begin{array}{l}\text { Van } 4 \\
\text { 2020www.vanguardngr.com }\end{array}$ & $\begin{array}{l}\text { Insecurity: Bandits operate for } 12 \\
\text { hours, raid bank, kill } 23 \text { - Vanguard }\end{array}$ & Bandits \\
\hline $\begin{array}{l}\text { www.vanguardngr.com } 18 \text { February } \\
2021\end{array}$ & $\begin{array}{l}\text { How bandits killed student, } \\
\text { abducted } 42-\text { Principal - Vanguard }\end{array}$ & Bandits \\
\hline $\begin{array}{l}\text { www.vanguardngr.com }>\text { News } 1 \\
\text { March } 2021\end{array}$ & $\begin{array}{l}\text { Bandits kill } 7 \text { persons in Kaduna - } \\
\text { Vanguard News }\end{array}$ & Bandits \\
\hline $\begin{array}{l}\text { www.vanguardngr.com } 9 \text { March } \\
2021\end{array}$ & $\begin{array}{l}\text { Bandits kidnap another } 30 \text { persons } \\
\text { in Niger - Vanguard }\end{array}$ & Bandits \\
\hline www.vanguardngr.com 3 may 2021 & $\begin{array}{l}\text { The Benuenisation of Niger State } \\
\text { and the Bandits war }\end{array}$ & Bandits \\
\hline $\begin{array}{l}\text { Www.vanguardngr.com } 11 \text { March } \\
2021\end{array}$ & $\begin{array}{l}\text { Bandits kill } 31 \text { people in separate } \\
\text { attacks in North - Local sources - } \\
\text { Vanguard News }\end{array}$ & Bandits \\
\hline
\end{tabular}

\section{Violent Attacks In South Eastern Nigeria}

\begin{tabular}{|l|l|l|}
\hline Source & Headlines & Perpetrators \\
\hline Dailytrust.com: 23 Feb 2021 & $\begin{array}{l}\text { Gunmen Kill Two Officers in Abia, } \\
\text { Set Police Station on Fire | Gunmen } \\
\text { Dailytrust }\end{array}$ & \\
\hline
\end{tabular}




\begin{tabular}{|c|c|c|}
\hline $\begin{array}{l}\text { Dailytrust.com } \\
\text { hoodlums...19 April } 2021\end{array}$ & $\begin{array}{l}\text { Hoodlums on Rampage in Anambra, } \\
\text { attack Police Station }\end{array}$ & Hoodlums \\
\hline Dailytrust.com 9 March 2021 & $\begin{array}{l}\text { Hoodlums set Abia police station on } \\
\text { fire | Dailytrust }\end{array}$ & Hoodlums \\
\hline $\begin{array}{ll}\text { Www.premiumtimesng.com } & 19 \\
\text { March } 2021 & \end{array}$ & $\begin{array}{l}10 \text { police officers killed; six stations } \\
\text { razed in two weeks }\end{array}$ & Unidentified \\
\hline$\frac{\text { www.premiumtimesng.com }}{\text { April } 2021}$ news 5 & $\begin{array}{l}\text { How gunmen attacked Owerri } \\
\text { prison, freed } 1844 \text { inmates - Official } \\
-\end{array}$ & Gunmen \\
\hline$\frac{\text { Www.premiumtimesng.com }}{\text { April } 72021}$ news & $\begin{array}{l}\text { Gunmen set another police facility } \\
\text { ablaze in Imo - }\end{array}$ & Gunmen \\
\hline$\frac{\text { Www.premiumtimesng.com }}{\text { April } 82021}$ news & $\begin{array}{l}\text { Gunmen attack third police station } \\
\text { in Imo in less than } 72 \text { hours }\end{array}$ & Gunmen \\
\hline$\frac{\text { Www.premiumtimesng.com }}{12 \text { April } 2021}$ news & $\begin{array}{l}\text { Gunmen attack Ebonyi community } \\
\text { hours after South-east governors' } \\
\text { security meeting. }\end{array}$ & Gunmen \\
\hline $\begin{array}{l}\text { Www.premiumtimesng.com regional } \\
27 \text { April } 2021\end{array}$ & $\begin{array}{l}\text { Gunmen kill five police officers, } \\
\text { abduct one in Imo }\end{array}$ & Gunmen \\
\hline $\begin{array}{l}\text { Www.premiumtimesng.com } \text { May } 9 \\
2021\end{array}$ & $\begin{array}{l}16 \text { police officers killed in Nigeria } \\
\text { last week }\end{array}$ & Unidentified \\
\hline$\frac{\text { Www.premiumtimesng.com } 23 \text { May }}{2021}$ & $\begin{array}{l}\text { Gunmen attack another police } \\
\text { station, kill officer }\end{array}$ & Gunmen \\
\hline$\frac{\text { www.premiumtimesng.com news } 25}{\text { May } 2021}$ & $\begin{array}{l}\text { Police operatives, hoodlums in gun } \\
\text { battle in Owerri }\end{array}$ & Hoodlums \\
\hline $\begin{array}{l}\text { punchng.com: gunmen-who-attack... } \\
6 \text { April } 2021\end{array}$ & $\begin{array}{l}\text { Gunmen who attacked Imo prison, } \\
\text { police command are cowards, says } \\
\text { Osinbajo - }\end{array}$ & Gunmen \\
\hline punchng.com: 29 April 2021 & $\begin{array}{l}\text { IPOB attacks on South-South states } \\
\text { provocative, unacceptable - Niger } \\
\text { Delta group }\end{array}$ & IPOB \\
\hline saharareporters.com 5 March 2021 & $\begin{array}{l}\text { Nigeria's Protectors Turned Victims: } \\
17 \text { Policemen Killed By Hoodlums } \\
\text { In South-East, South-South in } 2021\end{array}$ & Hoodlums \\
\hline www.thisdaylive.com 20 April 2021 & $\begin{array}{l}\text { Manhunt Launched for Attackers of } \\
\text { Anambra Zonal Police Headquarters }\end{array}$ & Attackers \\
\hline www.thisdaylive.com 25 April 2021 & $\begin{array}{l}\text { Imo Boils Again as Hoodlums } \\
\text { Attack Uzodimma's Country Home }\end{array}$ & Hoodlums \\
\hline $\begin{array}{l}\text { www.vanguardngr.com }>\text { News } \\
\text { April } 52021\end{array}$ & $\begin{array}{l}\text { BREAKING: Owerri prison break, } \\
\text { hundreds freed }\end{array}$ & Unidentified \\
\hline www.vanguardngr.com April 62021 & $\begin{array}{l}\text { Mayhem in Owerri: Armed men } \\
\text { burn prison, free } 1,844 \text { inmates, }\end{array}$ & Armed Men \\
\hline
\end{tabular}


bomb Police HQ

\section{Understanding Media Effects}

Mass media strengthen democracy, while democracy depend on people voting. Voting largely depends on people being informed. Therefore, news media keeps the public informed. Politicians and media giants understand this secret but the news media is also hugely susceptible to the pressures of marketplace. The media needs the trust and money of its readers to subscribe. To gain this, the media uses any means "necessary". It's not a surprise therefore that, campaigns rely heavily on talk programs and news coverage, and our political leaders communicate with the public via the media, press conferences, and political speeches. Hence, scapegoating and political campaigns are now centered on television. Republicans spent two-thirds of their budget on television ads for George Bush in 1992 (Elizabeth, 2008).

The concept of media effects is simple to grasp. It is self-evident that anything that takes up so much of our money and time has a big impact on our lives. The average person is awake for approximately $20 \%$ of the time, watches roughly 7 hours of television each day at home, and listens to the radio for approximately 22 hours per week (Elizabeth, 2008). Lippmann stated in 1922 that mass communication may become the foundation for people's worldviews. Similarly, Laswell thought of mass communication as a tool for deception and social control. He identified the following media-related effects: (a) the impact of media violence on violent behavior, (b) the effect of media images on the social construction of reality, (c) the effects of media bias on stereotyping, (d) the effects of erotic and sexual material on attitudes and objectionable behaviors, and (e) how media forms affect cognitive function and style (Elizabeth, 2008).

In this regard, Sharyl accurately observed that the voting public is constantly bombarded by a plethora of storylines, some of which are founded on grains of reality and others which are entirely made up for the audience. Trump was called several names, some ofthe names include: racist, crooked, liar, cheat, white nationalist, socialist, womanizer, misogynist, corrupt, xenophobic, homophobic, Islamophobic, anti-immigrant, basket of deplorables, fraudster, loser, alt-right, deluded, dangerous, mentally ill, pay-for-player, and tax cheat. 2016 campaign shatters all records in the smear department, aided by ideologues, sleazy political operators, and dark Internet firms looking for clicks (Sharyl, 2017).

\section{The Need for Media Literacy}

The smear is a pliable creature with no loyalty or remorse. It's content to serve as a weapon for the government, corporations, special interests, and political parties. Everyone wants to be the master of it. However, some people are far better at it than others. The smear artist, a character assassin motivated by passion, ideology, and money, enters the picture. The smear industry is endless and extremely profitable. It has quietly grown into one of Washington, D.C.'s top whitecollar industries. Thousands of people have become wealthy as a result of it. It's quickly becoming one of our most important global exports (Sharyl, 2017).

We are living in a age define by media technology, for many of us the majority of our waking hours is largely centre around interacting with the media. From checking our emails, charting on other social media platforms to retiring to our tv after a long day of work. The Media is everywhere, on our phones, laptops, tablet, tv, radio gas station even in the hospital. The media has become a common place that we do not often think about the messages communicated to us through these platforms. 
One of the biggest casualties is nonpartisan investigative journalism. The PR spinmeisters, corporate collusion, and political flacks have made it increasingly difficult for good reporters to do independent reporting on important topics. Good reporters hate what's happened to the news. The unsettling predominance of "transactional journalism" has paved the way for covert coordination between journalists and special interests. As a result, separating fact from fantasy might be difficult. Even self-proclaimed truth tellers and fact-checkers have been co-opted. We are left extremely vulnerable as corporations and political operatives jockey for control, they have found uncanny success in exploiting news organizations, quasi-news outlets, and brokers of so-called fake news to lend legitimacy to their efforts. As citizens, it is important therefore that we carefully evaluate where the message is coming from and always remember that the message is created by someone trying to communicate something to the public. Citizens should also realize that a content producer(s) is paid by somebody, or organization. It is important that content consumers ask these questions, who's is trying to communicate to them and take a closer look at where the media message is coming from.

More so, as consumers of news content, we should always analyze the main ideas of the message. Citizens should be increasingly fascinated about what is not said or what doesn't fit in (what is "economically" said) to analyse is to try to make sense out of the message. It is important to identify what the creator is trying to say to you as the reader/ audience. More so, how did you act after receiving the information? Most people will immediately swing in action. Citizens should not hurriedly accept what is presented as the only available fact. It is the responsibility of both the creator and receiver of media content to first verify news information before sharing. In addition, citizens should be circumspect when sharing media message with others: How do we share what we have seen, heard or read with friends and family. Do we do that in person, post on Facebook or just retweet without mulling over the content and thereby helping media creators spread fake news or hate? Citizens should responsibly create media content to share with others. In summary, being media literate is about thinking critically about media message we consumed. Ask questions about the media we interact with and being aware about how we participate in the creation of media.

\section{Conclusion}

Scholars and ordinary citizens alike have come to the realization of the power and essence of the Mass media. The media since it gained prominence have proven it mantle, the reason the media has been accorded the fourth place in the hierarchy of estates in the realm after the three major apparatuses of government. It is important that the media must understand the power it has and must try to uphold the sanctity, ethos and principle of neutrality and of balance reportage at all time. The Nigerian media as an de facto instrument of state must wake up to its neutral role and must inform the public without biases and sentiments.

The Fulani are a people like all people within the Nigerian geography, they do not have the monopoly of violence, their actions must be reported when it goes against state laid down dictums like all other members of the Nigerian state, they should not be allowed to alienated and ostracized within the state as these feelings breeds natural discontent, a case not too far away is the Igbo who have become great agents of division and secession because of the place they feel the Nigerian state has positioned them. News reportage on issues of crime and in this case Banditry must not be reported along ethnic or religions lines, they should be reported as crimes and as crimes alone, a people must not be reported to be seen as those with the monopoly to commit a particular kind of crime and banditry whether in the north or south should be reported as such. 


\section{References}

Abuja Schools Shut Down as Truckload of Bandits Arrives In Border Town Leadership.ng 6 May 2021.

Addo, P. (2006). Cross-Border Criminal Activities in West, Africa: Options for Effective Responses, Kofi Annan International Peace Keeping Training Centre Cantonments, Accra Ghana.

Ahmed, T. M (ND). Banditry Dynamism and Operating Pirating Pattern of Crime in Northwest: A Threat to National Security

Anka A.S (2017). Emerging Issues in Zamfara Armed Banditry and Cattle Rustling: Collapse of the Peace Deal and Resurgence of Fresh Violence. International Journal of Innovative Research and Development, 6 (12): 161-170.

American's gun syndrome. Inside America with GhidaGakhry 31 March 2021 https://youtu.be/Whq0uFqcn84

America's gun obsession. Inside America with Ghida Fakhry 23 September 2020 https://youtu.be/WI5jgPCpWhI

At least bandits killed 21 kidnapped 40 others www.dailytrust.com

Bandits Kill 8, Abduct 19 Female Anglican Church Members, 6 Others in KadunaLeadership Newspaper April 72021

Bandits Burn Kaduna Church, Kill Eightby Saharareporters, New York May 19, 2021

Bandits kidnap another 30 persons in Niger - Vanguard www.vanguardngr.com 9 March 2021

Bandits kill 7 persons in Kaduna - Vanguard News www.vanguardngr.com News 1 March 2021

Bandits kill 31 people in separate attacks in North: Local. Vanguard News www.vanguardngr.com 11 March 2021

Bandits invade emir's farm, kill son | Premium Times Nigeria www.premiumtimesng.com > 21 May 2021

Bandits, Violence and the Numbers Game, www.premiumtimesng.com 12 March 2021

Bandits kill eight, raze houses, church in Kaduna - Punch Newspapers www.punchng.com bandits-kill-eight-ra 19 May 2021

Bandits kill Father; son, 2 others in Southern Kaduna - Vanguard News www.vanguardngr.com News 12 April 2021

Bandits abduct women, children in Kaduna - Vanguard News www.vanguardngr.com > News 21 Feb 2021

Bandits getting more intelligence reports than military'www.punchng.com Punch Newspapers 21 July 2019

Dining with the devil: How villagers' co-habit with bandits www.dailytrust.com Mon May 24 2021

Elizabeth M Perse (2008). Media Effects and Society. Published by Lawrence Erlbaum Associates, Publishers Mahwah, New Jersey.

Felix H, Karsten, D and Bela, G (2018). Automated identification of media bias in news articles: an interdisciplinary literature review. Published in International Journal on Digital Libraries 20:391-415 https://doi.org/10.1007/s00799-018-0261-y

Getting A Gun Is Like Buying Bread, Says 'Repentant' Bandits' Leader Behind Kankara Schoolboys Abduction, Daudawa: saharareporters.com 2021/02/18

Gunmen kill five police officers, abduct one in Imo | Premium Times Nigeria www.premiumtimesng.com regional 27 April 2021

Gunmen attack another police station, kill officer - Premium Times Nigeria www.premiumtimesng.com 23 May 2021

Gunmen attack third police station in Imo in less than 72 hours - Premium Times Nigeria www.premiumtimesng.com April 82021 
Gunmen storm Nigerian prison, free inmates - Premium Times Nigeria www.premiumtimesng.com

Gunmen Kill Two Officers in Abia, Set Police Station On Fire www.dailytrust.com breaking hoodlums 23 Feb 2021

Gunmen attack Ebonyi community hours after South-east governors' security meeting PremiumTimes Nigeria www.premiumtimesng.com 12 April 2021

Gunmen set another police facility ablaze in Imo - Premium Times Nigeria www.premiumtimesng.com April 72021

Gunmen who attacked Imo prison, police command are cowards, says Osinbajo - Punch Newspapers www.punchng.com 6 April 2021

Helen, E.F., Rosemary E.A H., Julian, M. and Anne. K.M.D (2005): Narrative and Media. Published in the United States of America by Cambridge University Press www.cambridge.org

Hoodlums on Rampage in Anambra, attack Police Station www.dailytrust.com breaking hoodlums 19 April 2021

Hoodlums set Abia police station on fire www.dailytrust.com just-in-hoodlums 9 March 2021

How Katsina became hotbed of banditry Dailytrust.com 16 January 2021

How bandits terrorized Kagara for years before students abduction www.premiumtimesng.com 26 Feb 2021

How gunmen attacked Owerri prison, freed 1844 inmates - Official - Premium Times Nigeria www.premiumtimesng.com news 5 April 2021

How bandits killed student, abducted 42 - Principal - Vanguard www.vanguardngr.com 18 February 2021

Insecurity: Bandits operate for 12 hours, raid bank, kill 23 - Vanguardwww.vanguardngr.com 4 September 2020

Imo Boils Again as Hoodlums Attack Uzodimma's Country Home www.thisdaylive.com 25 April 2021

IPOB attacks on South-South states provocative, unacceptable - Niger Delta group www.punchng.com 29 April 2021

Kaduna abductions: Banditry now war situation, govt should cooperate -Gumi - Punch

Newspapers www.punchng.com kaduna-abductions-.24 April 2021

Manhunt Launched for Attackers of Anambra Zonal Police Headquarters www.thisdaylive.com 20 April 2021

Mayhem in Owerri: Armed men burn prison, free 1,844 inmates, bomb Police HQ www.vanguardngr.com April 62021

Nigeria's Protectors Turned Victims: 17 Policemen Killed By Hoodlums In South-East, South South in 2021 www.saharareporters.com 5 March 2021

Owerri prison break, hundreds freed - Vanguard News www.vanguardngr.com April 52021

Police operatives, hoodlums in gun battle in Owerri - Premium Times Nigeria www.premiumtimesng.com news 25 May 2021

Police confirm attack on its Imo headquarters, prison, blame IPOB www.premiumtimesng.com 5 April 2021

Police continue VIP duties as bandits, terrorists kill over 269 in Aprilwww.punchng.com 1 May 2021

Rufai, M.A. (2016). "The Role of Vigilante Groups in the Fight against Rural Banditry in Zamfara State, North-Western Nigeria". Degel Journal of the Faculty of Arts and Islamic Studies, Usmanu Danfodiyo University, Sokoto (UDUS), Nigeria. 13 (6): 300-302.

Suleiman IgudaLadan and Bilkisu Usman Matawalli (2020). Impacts of Banditry on Food Security in Katsina State, Nigeria. Published in Official Publication of Direct Research Journal of Agriculture and Food Science: Vol. 8, 2020, ISSN 2354-4147 
Sharyl, A. (2017). The Smear: How Shady Political Operatives and Fake News Control what you see, what you think and how you vote. Published by HarperCollins e-books.

The Benuenisation of Niger State and the Bandits war www.vanguardngr.com 3 may 2021

We killed students of Kaduna private varsity to show govt has failed Dailytrust.com 3 May 2021

What is media literacy| with Natalie https://youtu.be/dt2CaHXuyWU14 July, 2020

Villagers Sign Peace Deals with Bandits in Niger THISDAYLIVE www.thisdaylive.com

Ziyanda S (2018). Terrorism as Controversy: The Shifting Definition of Terrorism in State Politics

2M Nigerians Displaced by Insurgency, Banditry- FG Leadership newspaper Jan 82021

6 Killed, 5 Abducted as Bandits Displace 3000 In Niger Communities Leadership newspaper Jan 252021

4 policemen, 44 others killed in fresh gun attackswww.dailytrust.com 24 may 2021

10 police officers killed; six stations razed in two weeks www.premiumtimesng.com 19 March 2021

323 killed, 949 kidnapped in Kaduna in three months - Report - Premium Times Nigeria www.premiumtimesng.com 30 April 2021

16 police officers killed in Nigeria last week - Premium Times Nigeria

www.premiumtimesng.com May 92021 